\title{
Non-alcoholic fatty liver disease and mineral waters of Ukraine - opportunities of application (experimental-clinical studies)
}

\author{
Zabolotna Irina B $^{1}$., Gushcha Sergey $\mathbf{G}^{\mathbf{1}}$., Mikhailenko Vladimir $\mathbf{L}^{2}$
}

Corresponding author: Gushcha Sergey G., E-mail address: gushchasergey@rambler.ru

1. State Institution «Ukrainian Scientific-Research Institute of Medical Rehabilitation and Balneology, the Ministry of Public Health of Ukraine», Odessa.

2. Department of Medical Rehabilitation Odessa National Medical University, Odessa, Ukraine

\begin{abstract}
Non-alcoholic fat liver disease (NAFLD) is an urgent problem of modern healthcare and ranks first among all liver diseases worldwide, assuming the nature of an epidemic. The pathogenesis of NAFLD is complex and insufficiently studied, and therefore pharmacological therapy is not always effective and causes negative side effects (or complications). Treatment with mineral waters (MW) is one of the most effective methods of treating diseases of the digestive system and metabolic disorders. Objective: to study the effect of sulphate MW on metabolic disturbances in rats with the experimental NAFLD model for the purpose of scientifically substantiating its use in the complex of treatment of patients. Morphological studies have established that the use of sulfate MW in healthy animals causes an increase in the functional activity of the liver and stomach, which indicates a pronounced biologic activity of this MW. In animals under the influence of sulphate MW was determined a significant reduction in hepatic steatosis according to the morphological study of biopsy specimens, restoration of the processes of bile formation and bile secretion, positive dynamics in the restoration of energy-dependent transmembrane ion transport. Clinical studies in the complex treatment of NAFLD with the use of sulphate MW established normalization of lipid metabolism, improvement of the functional state of the liver, decreased insulin resistance, recovery of adiponectin secretion.
\end{abstract}

Key words: non-alcoholic fat liver disease, sulphate mineral water, dyslipidemia, insulin resistance.

\section{Introduction}

Non-alcoholic fat liver disease (NAFLD) is an etiologically heterogeneous disease combined with a common pathomorphological phenomenon: excess accumulation of neutral fat-triglycerides and free fatty acids both inside the hepatocytes and extracellularly with progressive aseptic inflammation and subsequent fibrogenesis [1, 2, 3]. Nonalcoholic steahepatitis (NASH), depending on the etiology and age, occurs in 5-8\% of the adult population or in 12$40 \%$ of patients with NAFLD). In the USA, the frequency of occurrence of NAFLD in middle-aged people reaches $46 \%$, of which NASH is diagnosed in $30 \%$ of patients, more often - in the Hispanic population.

The evolution of scientific knowledge over the past 30 years has led to the realization that NAFLD is the most common and socially significant disease among all diffuse liver diseases, more and more researchers view the NAFLD as a multi-systemic disease. The role of NAFLD in the formation and progression of cardiovascular pathology, the risk of developing type 2 diabetes and chronic kidney disease have been proven. The relationship between NAFLD and psoriasis, steatosis of the pancreas, cancer of various localizations is considered $[4,5,6]$.
Currently, there is no generally accepted therapy for NAFLD. The modern treatment of this disease is determined by the presence of risk factors associated with the NAFLD in a particular patient. Therapeutic approaches are based on dietary recommendations, the regime of physical activity, the long-term use of several classes of drugs (the drugs of choice in the treatment of NAFLD are insulin-telltesters, statins, antioxidants, hepatoprotectors, vitamin E), [6, 7]. However, the results of such therapy are far from desirable, accompanied by side effects and risk of polypharmacy [8], which makes it urgent to search for new non-medicament therapeutic treatment strategies.

Meanwhile, the possibility of using mineral waters in the complex treatment of such patients is practically not considered. Scientific achievements of the Ukrainian balneological school prove that mineral water treatment is one of the main methods of therapy of diseases of the digestive system and metabolic disorders, because, due to its therapeutic effects, mineral waters exceed many medicines. However, they do not have side effects and allergic reactions, overloading the patient's body with chemicals [9 12]. In connection with this, it is of scientific and practical interest to study the effect of mineral waters in the treatment of NAFLD. 
One of the ethical aspects and security aspects is the inability to exercise such an effect on the human body; therefore, in modern medicine, research on animals is in the first place [13, 14]. In addition, carrying out experimental work allows to reduce the time to study the individual mechanisms of the development of disfunction, their role in the pathogenesis of the disease and to investigate the influence of medicines and means of natural origin on the course of the pathological process $[15,16]$.

That is why, the purpose of the work was to evaluate the effectiveness of the internal application of mineral diluted water from well No. 3-k (Nynivskoe deposit, Morshin resort, Lviv region) in salt concentration of $3.0-4.0 \mathrm{~g} / \mathrm{dm}^{3}$ in rats with a model of non-alcoholic fat liver disease and the rationale expediency and effectiveness of its use in the complex of treatment of patients with NAFLD.

\section{Materials and methods}

The experiment was carried out on 40 white female rats with a body weight of 180.0-200.0 g, in accordance with the rules regulated by the relevant documents [17]. In the first stage of the study to determine the presence of biological activity of sulfate MW, an additional group of healthy animals was selected, which received this MW during the course of 15 days in a probing regime in the amount of $1 \%$ of body weight. At the second stage of research the animals were divided into 3 groups. The first comparison control group was made up of healthy animals. The second one is animals with a model of NAFLD, with free access to drinking troughs with tap water. The third group consisted of animals with a model of NAFLD with free access to drinkers with standing tap water and additionally received mineral diluted water of wells. No. 3- $\mathrm{K}$ with mineralization of 3.0-4.0 g / $\mathrm{dm}^{3}$. MW were injected into the esophagus of animals with a soft probe with olive, once a day with a course from 15 days, at a dose of $1 \%$ of body weight, in the evening, taking into account the peculiarities of the daily biorhythm of animals.

The model of NAFLD in rats was reproduced by subcutaneous administration of a $70 \%$ solution of chloroform on sunflower oil, 2 times a week for one month at a rate of $0.03 \mathrm{ml}$ per $100 \mathrm{~g}$ of body weight of the rat. To the usual ration of animals (full feed and grain mixture in the amount of $20 \mathrm{~g}$ ) is added $5 \mathrm{~g}$ of beef fat, ground with $5 \mathrm{~g}$ of white breadcrumbs per animal. Instead of drinking water, rats get only $5 \%$ aqueous fructose solution in the regime of free access [13].

After completion of the experiment, the animals were removed from the experiment under ether anesthesia and macroscopic and microscopic examination of the liver. Rats were prepared with 2 pieces of liver, $1 \mathrm{~cm}^{3}$ in volume. The first piece was carried through spirits of increasing concentration and poured into the celloidin. Histological sections were stained with hematoxylin-eosin and microscopic studies of structural changes in the liver were performed. The second piece was frozen with dry carbon dioxide $\left(-70^{\circ} \mathrm{C}\right)$, histochemical reactions were performed on the prepared cryostat sections to determine the activity of succinate dehydrogenase (SDH) and lactate dehydrogenase (LDH) in Loyd's form. Activity was expressed in conventional units of optical density.

The systemic nature of changes in the body of rats during the modeling of NAFLD and their correction by intragastric administration of MW was assessed by biochemical indices. As the biochemical markers were used the total protein content in the blood serum, the level of total bilirubin and its fractions, the level of aminotransferases (ALT and AST), the level of alkaline phosphatase. By biochemical methods was determined the activity of ATPs (Mg2 + / Ca2 + dependent and Mg2 + / Na + / K + -dependent ATPs) in mitochondria. The state of the LPO / AOP system was determined by the level of malonic dialdehyde (MDA) and the activity of erythrocyte catalase. Methodological methods and techniques used in conducting experimental studies are in line with methodological recommendations [18].

In clinical observations were studied general clinical symptoms, biochemical blood indices, including lipid metabolism indices, insulin resistance according to the HOMA-IR index, adipocytokine levels-leptin and adiponectin, and ultrasonographic studies of digestive organs. For the clinical part of the study, 40 patients with NAFLD were under observation. $62.5 \%$ of patients had NAFLD at the stage of steatosis, the rest had NASH of minimal activity. Two groups of patients were formed. The first group (control group, 20 people) had the complex of treatment with diet therapy and physical exercises. The second group (main, 20 people) in addition to this received additional MW. The time of water intake was determined by the acid-forming function of the stomach: and were 30, 45 and $60 \mathrm{~min}$. before meals. 
The course of treatment was 21-24 days. Among the patients, women predominated, the average age was (52.56 \pm 2.14$)$ years.

Statistical processing of the obtained data was carried out using programs for biomedical research Statistica and Exel. The average values are given in the form $(M \pm m)$, where $M$ is the average value of the indicator, $\mathrm{m}$ is the standard error of the mean. Reliable changes were those that were within the limits of reliability according to Student's tables $<0.05$.

The study used mineral diluted water (MDW) from the well No. 3-k, the Nynivsky deposit of the Morshin resort (Lviv region). By chemical composition, this water is a low-mineralized sodium sulphate. The chemical formula has the following form:

$$
\mathrm{M}_{3,0-4,0} \quad \frac{\mathrm{SO}_{4}}{(\mathrm{Na}+\mathrm{K}) \text { 82-81 Cl 16-20 }}
$$

\section{Results and discussions}

Morphological studies of the organs of the gastrointestinal tract of healthy rats receiving a course of MW revealed such changes. The stomach has a submucosa of the usual form, fibers are tightly packed, fibroblasts are few. The glands in a mucous membrane have a round form. In epitheliocytes there are juicy nuclei and a bright eosinophilic cytoplasm. Activity of the SDG - 7,00 $\pm 0,19$ c.u; LDH activity is 6,00 $\pm 0,17$ c.u.. Liver - the lobular structure of the liver is preserved, intervertebral spaces are widespread. Hepatocytes are well-ordered. The kernels are small, granulated in the cytoplasm. The activity of the EDL is reduced $-5.00 \pm 0.19$ c.u (p $\leq 0.01)$ at $7.0 \pm 0.15$ in group 1 rat; LDH activity is $\underline{6,00 \pm 0,44 \text { c.u). }}$

Thus, after the course of internal application of sulfate MW in healthy rats, increased functional activity of the stomach and liver, with a decrease in the activity of processes of energy metabolism in the liver. The established effect of MW action can be considered as a non-specific protective adaptive response-response of an organism to the influence of the stressor factor of weak intensity, which is used by the MW. The obtained data substantiated the conduct of the second phase of experimental studies to determine the presence of corrective effects of sulfate MW in rats from NAFLD.

After 30 days from the beginning of the modeling of NAFLD, visually the liver is not enlarged, the surface is smooth, shiny, the anterior edge is sharp, the liver tissue is brownish-yellow. At histological research lobular organization of hepatic tissue is preserved. The central vein is thin-walled, stagnant, fullblooded. Unlike intact animals, small clusters of lymphocytes are visually recognized in the part of the lobules near the central vein. Hepatocytes in the central part of the lobule are collected in beams, which radially diverge from the central vein. Hepatocytes are of medium size, their cytoplasm is weakly basophilic, cloddy. In a significant part of the hepatocytes fatty vacuoles of different sizes were found. Inter-beam spaces are expanded. Kupffer cells with swollen nuclei. As for hepatocytes, there are no cells with two nuclei among them. There were many large light-colored nuclei and hepatocytes with small dark nuclei.

SDH activity is uniform over the whole surface of the cut of the lobe and is - $(5,0 \pm 0,27)$ c.u. $(p<0.01)$ at $(7.0 \pm 0.15)$ in group 1 rats. LDH activity remains uniform throughout the surface of the cut and is - (6.0 $\pm 0.19)$ c.u. at $(6.0 \pm 0.15)$ c.u. in the rats of group 1 . The foregoing indicates a decrease in the intensity of the functional activity of the liver (dystrophy), apparently due to the weakening of the oxidationreduction processes of the energy cycles and the weakening, in this connection, of other aspects of metabolism, including lipid metabolism.

In group 3, macroscopic examination of the liver of the rats showed that the surface of the liver is smooth, shiny, moist, the anterior margin is pointed, the color of the tissue is brown. At microscopic research it is established, that the partial organization of structure of a hepatic tissue is kept. Interlobar interstitial plates are thin, dense, represented by close-packed fibrous fibers and a small amount of fibroblasts. Interlobar interstitial plates are thin, dense, represented by closepacked fibrous fibers and a small amount of fibroblasts. It is not possible to separate the fibrocytes visually from the fibers. The fibers themselves are long, delicate. Vessels of triads thin-walled, moderate blood filling. Interstitial bile ducts are the same. In the center of the lobule is the central vein, with a somewhat thickened (fibrous) wall, the blood filling is moderate. There were no diapedesis lymphocytes triads around the vessels. In the central vein, there are single lymphocytes. Hepatocytes in 2/3 of the central part of the lobule are collected in beams, in the remaining part they form an array. Inter-beam spaces are expanded. Kupffer cells are flat. 
The cytoplasm of hepatocytes is homogeneous, weakly basophilic. It is noteworthy that the density of the cytoplasm of hepatocytes is not equal in cross section, this causes the unevenness of its color. In individual hepatocytes, small vacuoles are found in small amounts. No two-nuclear cells were detected. In most hepatocytes, the nucleus is small, darkly colored. In the part of hepatocytes, the nucleus is round, of medium size, of moderate staining with an indistinct edge.

Histoenzymatic studies have shown that the activity of SDH is the same over the entire surface of the cut and is $(6.5 \pm 0.15)$ c.u. LDH activity is also monotonous on the surface of the cut of the fraction and class $(6.0 \pm 0.23)$ c.u.

Thus, the use of this MDW was accompanied by a significant decrease in manifestations of lipid dystrophy of hepatocytes, and signs of the presence of elements of inflammatory reaction and inactivation of liver function.

Assessment of biochemical indicators revealed the following (Table 1). In the modeling of NAFLD, there is a significant decrease in ACT activity $(\mathrm{p}<0.01)$ with a simultaneous increase in ALT activity ( $\mathrm{p}$ $<0.001$ ), i.e, the detoxification function of the liver in these animals is not only weakened but also unbalanced which is confirmed by a decrease in the Ritis index $(\mathrm{p}<0.01)$.

A significant increase in the creatinine content $(\mathrm{p}$ $<0.01$ ) and urea concentration ( $\mathrm{p}<0.001)$ in the blood plasma indicates an increase in the accumulation of toxic metabolites in the rats. Since the content of the total protein remains within the limits of physiological norms, it can be assumed that despite the violation of the detoxification processes, the protein-synthesizing function of the liver is preserved.

It should be noted that imbalance arises not only in the detoxification function of the liver, but also in the processes of energy-dependent transmembrane transport, as evidenced by multidirectional changes in the activity of ATP-as. If the activity of Mg2 + / Ca2 + dependent ATPs increases ( $p<0.05$ ), then the activity of $\mathrm{Na}+/ \mathrm{K}+$ dependent ATPs is reduced ( $\mathrm{p}$ $<0.01$ ). Since this activity is related to the transport of ions, which provide the transmembrane potential, which is the main element of the energy supply to the vital activity of the cell, it can be assumed that the above metabolic changes, including lipid accumulation, are caused, in particular, by ion- dependent disturbances in energy supply. An increase in the content of lipid peroxidation products ( $p$ $<0.001)$ and a decrease in catalase activity $(\mathrm{p}<0.02)$ were established, which indicates activation of the processes that cause the destruction of cell membranes and weaken the processes of their protection. Since the activity of alkaline phosphatase (p <0.01), an enzyme, increases simultaneously, phosphorus releases, including phospholipids from hepatocyte membranes, it can be assumed that the functioning of hepatocytes will be seriously impaired, which explains the accumulation of lipids in them.

An increase in AST activity was established in animals receiving MDW ( $<0.001)$ (Table 1$)$.

Improvement of the functioning of liver cells and their release from pathological deposition of lipids may be due to the improvement of membrane-bound energy supply processes. This assumption is supported by a significant decrease in the activity of Mg2 + / Ca2 + dependent ATPs in the background of an increase in the activity of $\mathrm{Na}+/ \mathrm{K}+-$ dependent ATPs, which results in their ratio approaching the norm. Changes in the activity of ATPs and their balance indicate the restoration of energy-dependent transmembrane ion transport, which has a beneficial effect on vital processes. At the same time, a significant decrease in the content of lipid peroxidation products $(p<0.05)$ occurs against the background of a tendency to increase the activity of catalase, which indicates a restriction of the intensity of free radical lipid oxidation processes and positively affects the state of the hepatocyte membrane.

The obtained results of experimental studies became the basis for conducting clinical studies. The clinical picture of NAFLD in patients enrolled in the study was oligosymptomatic. Only a third of the patients were concerned with the manifestations of pain (severity or pain in the right hypochondrium, painfulness in the palpation of this area), most of the patients $(77.5 \%)$ presented complaints that characterize the syndrome of gastric and / or intestinal dyspepsia (bitterness in the mouth, nausea, heartburn, belching, bloating, constipation), which were more associated with the concomitant pathology of the digestive system. In the overwhelming majority of patients (80.0\%), overweight or obesity of I-II degree

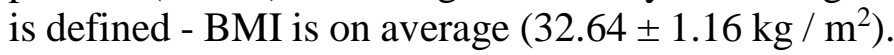
According to the biochemical study, an increase in the level of total bilirubin due to its indirect fraction in $32.5 \%$ of patients, alkaline phosphatase and GGT 
levels to $1.5 \mathrm{~N}$ - in $40.0 \%$ of people was revealed. Disorders of lipid metabolism were characterized by an increase in the level of total cholesterol (TCH) on average to $(6.63 \pm 0.19) \mathrm{mmol} / \mathrm{L}, \beta$-lipoproteins $(66.18 \pm 2.15)$ units, triglycerides - $(3.14 \pm 0,14)$ mmol / l, LDL on average to $(4,18 \pm 0,28) \mathrm{mmol} / \mathrm{l}$, decrease in HDL level on the average in the group to $(1,32 \pm 0,16) \mathrm{mmol} / \mathrm{l}$. The coefficient of atherogenicity averaged ( $4.58 \pm 0.32)$ units.

Table 1 Influence of the internal course use of MDW on the biochemical parameters of rats with the model of NAFLD, $(\mathrm{M} \pm \mathrm{m})$

\begin{tabular}{|c|c|c|c|c|c|}
\hline Index & $\begin{array}{l}\text { I group } \\
(n=20)\end{array}$ & $\begin{array}{l}\text { II group } \\
(n=10)\end{array}$ & $\mathrm{p}_{1}$ & $\begin{array}{l}\text { III group } \\
(n=10)\end{array}$ & $\mathrm{p}_{2}$ \\
\hline ALT, U / l & $81,40 \pm 1,83$ & $107,00 \pm 5,33$ & $<0,001$ & $98,66 \pm 2,53$ & $<0,01$ \\
\hline AST, U / l & $193,62 \pm 5,10$ & $156,27 \pm 8,04$ & $<0,01$ & $206,11 \pm 4,48$ & $>0,05$ \\
\hline Ritis index & $2,38 \pm 0,03$ & $1,54 \pm 0,09$ & $<0,01$ & $2,48 \pm 0,05$ & $>0,5$ \\
\hline Bilirubin total, $\mu \mathrm{mol} / \mathrm{l}$ & $4,04 \pm 0,14$ & $5,85 \pm 0,24$ & $<0,01$ & $4,52 \pm 0,33$ & $>0,1$ \\
\hline Bilirubin direct, $\mu \mathrm{mol} / 1$ & $1,31 \pm 0,03$ & $2,17 \pm 0,42$ & $<0,01$ & $2,29 \pm 0,27$ & $<0,01$ \\
\hline Bilirubin indirect, $\mu \mathrm{mol} / 1$ & $2,74 \pm 0,13$ & $3,68 \pm 0,45$ & $<0,01$ & $2,23 \pm 0,10$ & $>0,5$ \\
\hline Total protein, g / l & $68,70 \pm 2,74$ & $65,33 \pm 0,84$ & $>0,2$ & $68,19 \pm 0,97$ & $>0,5$ \\
\hline Creatinine, $\mu \mathrm{mol} / \mathrm{L}$ & $47,80 \pm 0,63$ & $57,43 \pm 2,84$ & $<0,01$ & $53,31 \pm 2,91$ & $>0,5$ \\
\hline Urea, mmol / l & $2,80 \pm 0,27$ & $6,67 \pm 0,21$ & $<0,001$ & $3,56 \pm 0,27$ & $>0,05$ \\
\hline $\begin{array}{l}\text { Mg2 + / Ca2 + -ATPs, } \\
\text { mg R / g of tissue }\end{array}$ & $9,11 \pm 0,93$ & $11,75 \pm 0,67$ & $<0,05$ & $8,75 \pm 0,59$ & $>0,5$ \\
\hline $\begin{array}{l}\mathrm{Mg} 2+/ \mathrm{Na}+/ \mathrm{K}+\text {-ATPs, } \\
\mathrm{mg} \mathrm{R} / \mathrm{g} \text { of tissue }\end{array}$ & $6,40 \pm 0,62$ & $3,72 \pm 0,24$ & $<0,01$ & $4,77 \pm 0,25$ & $<0,05$ \\
\hline $\mathrm{MDA}, \mathrm{nmol} /(\mathrm{xv} \cdot \mathrm{mg})$ & $5,94 \pm 0,21$ & $7,79 \pm 0,31$ & $<0,001$ & $6,85 \pm 0,27$ & $<0,05$ \\
\hline Catalase, $\%$ & $76,70 \pm 1,52$ & $68,91 \pm 2,14$ & $<0,02$ & $74,19 \pm 2,12$ & $>0,05$ \\
\hline Alkaline phosphatase, U / l & $369,19 \pm 12,41$ & $455,22 \pm 20,61$ & $<0,01$ & $422,66 \pm 18,30$ & $<0,05$ \\
\hline
\end{tabular}

Table 2 Dynamics of indicators of the functional state of the liver and HOMA index in patients with NAFLD under the influence of treatment, $(\mathrm{M} \pm \mathrm{m})$

\begin{tabular}{|c|c|c|c|c|c|}
\hline \multirow[b]{2}{*}{ Index } & \multirow[b]{2}{*}{ Baseline } & \multicolumn{2}{|c|}{ I group $(n=20)$} & \multicolumn{2}{|c|}{ II group $(n=20)$} \\
\hline & & $\begin{array}{l}\text { Before } \\
\text { treatment }\end{array}$ & $\begin{array}{l}\text { After } \\
\text { treatment }\end{array}$ & Before treatment & $\begin{array}{l}\text { After } \\
\text { treatment }\end{array}$ \\
\hline Bilirubin total, $\mu \mathrm{mol} / \mathrm{l}$ & $\begin{array}{l}\text { heightened } \\
\text { normal }\end{array}$ & $\begin{array}{l}23,83 \pm 3,36 \\
17,75 \pm 2,11\end{array}$ & $\begin{array}{l}21,14 \pm 1,89 \\
18,02 \pm 2,35\end{array}$ & $\begin{array}{l}26,54 \pm 2,95 \\
16,19 \pm 1,40\end{array}$ & $\begin{array}{l}16,63 \pm 2,34^{* *} \\
11,74 \pm 0,66\end{array}$ \\
\hline Alkaline phosphatase, U / l & $\begin{array}{l}\text { heightened } \\
\text { normal }\end{array}$ & $\begin{array}{l}139 \pm 6,02 \\
114 \pm 4,29\end{array}$ & $\begin{array}{l}136,56 \pm 5,87 \\
116 \pm 5,06\end{array}$ & $\begin{array}{l}138,62 \pm 6,12 \\
118,69 \pm 3,22\end{array}$ & $\begin{array}{l}116,46 \pm 4,98 * \\
112,63 \pm 4,33\end{array}$ \\
\hline $\begin{array}{l}\text { Gammaglutamyl-transpeptidase, } \\
\text { U / l }\end{array}$ & $\begin{array}{l}\text { heightened } \\
\text { normal }\end{array}$ & $\begin{array}{l}58,02 \pm 5,26 \\
34,85 \pm 3,19\end{array}$ & $\begin{array}{l}56,11 \pm 6,09 \\
33,89 \pm 4,52\end{array}$ & $\begin{array}{l}56,14 \pm 5,78 \\
32,44 \pm 2,66\end{array}$ & $\begin{array}{l}42,24 \pm 3,46 \\
29,08 \pm 3,09\end{array}$ \\
\hline $\mathrm{AlT}, \mathrm{mmol} /(\mathrm{h} \cdot \mathrm{l})$ & $\begin{array}{l}\text { heightened } \\
\text { normal }\end{array}$ & $\begin{array}{l}0,91 \pm 0,19 \\
0,36 \pm 0,16\end{array}$ & $\begin{array}{l}0,73 \pm 0,13 \\
0,29 \pm 0,19\end{array}$ & $\begin{array}{l}1,21 \pm 0,12 \\
0,39 \pm 0,05\end{array}$ & $\begin{array}{l}0,94 \pm 0,13 \\
0,22 \pm 0,03\end{array}$ \\
\hline AST, mmol / (h·l) & $\begin{array}{l}\text { heightened } \\
\text { normal }\end{array}$ & $\begin{array}{l}1,04 \pm 0,06 \\
0,34 \pm 0,09\end{array}$ & $\begin{array}{l}0,99 \pm 0,06 \\
0,30 \pm 0,03\end{array}$ & $\begin{array}{l}0,56 \pm 0,08 \\
0,28 \pm 0,02\end{array}$ & $\begin{array}{l}0,42 \pm 0,05 \\
0,26 \pm 0,02\end{array}$ \\
\hline Total cholesterol, mmol / l & heightened & $7,03 \pm 0,48$ & $6,97 \pm 0,43$ & $5,87 \pm 0,23$ & $5,14 \pm 0,19 *$ \\
\hline ß-lipoproteids, units. & heightened & $66,84 \pm 2,09$ & $62,17 \pm 1,90$ & $62,69 \pm 3,49$ & $54,22 \pm 2,40 * *$ \\
\hline Triglycerides, mmol / l & heightened & $2,90 \pm 0,31$ & $2,88 \pm 0,23$ & $2,67 \pm 0,28$ & $2,14 \pm 0,23$ \\
\hline $\mathrm{HDL} \mathrm{mmol} \mathrm{/} \mathrm{l}$ & reduced & $1,52 \pm 0,11$ & $1,54 \pm 0,12$ & $1,09 \pm 0,13$ & $1,26 \pm 0,15$ \\
\hline $\mathrm{LDL} \mathrm{mmol} / \mathrm{l}$ & heightened & $3,57 \pm 0,20$ & $3,36 \pm 0,18$ & $3,69 \pm 0,33$ & $3,08 \pm 0,18$ \\
\hline Glucose, mmol / l & normal & $6,02 \pm 0,36$ & $5,87 \pm 0,42$ & $5,64 \pm 0,27$ & $5,25 \pm 0,21$ \\
\hline Insulin, $\mu \mathrm{U} / \mathrm{ml}$ & normal & $18,74 \pm 0,82$ & $16,67 \pm 0,94$ & $15,36 \pm 1,09$ & $11,78 \pm 1,12^{*}$ \\
\hline HOMA-IR index, units & heightened & $5,29 \pm 0,44$ & $4,11 \pm 0,56$ & $3,62 \pm 0,36$ & $2,72 \pm 0,24 *$ \\
\hline
\end{tabular}


Note: the value of $\mathrm{P}$ is calculated before and after treatment; * - $\mathrm{p}<0.05$; ** $-\mathrm{p}<0.02$

Thus, the level of adiponectin significantly increased and averaged $(22.18 \pm 3.07) \mathrm{ng} / \mathrm{ml}(\mathrm{p}<0.05)$, and the change in leptin level was characterized by a tendency to decrease, which averaged over the group $(17.08 \pm 2.52) \mathrm{ng} / \mathrm{ml}(\mathrm{p}>0.05)$, No significant changes in the ultrasound pattern of the liver were observed.

Notes: p1 - the reliability is calculated between the indices of the I and II groups; p2 - the reliability is calculated between the indices of the I and III groups. It can be assumed that under the influence of this MW, the transamination processes in hepatocytes are restored, that is, the function of detoxification is improved, which is confirmed by the normalization of the Ritis index (p <0.001). Similarly, the normalization of the level of total bilirubin $(\mathrm{p}<0.01)$ due to the indirect fraction in the plasma can be traced, which supports the restoration of the processes of bile formation and bile secretion and confirms the restoration of detoxification processes at the hepatocyte level. Since the urea level decreases simultaneously ( $\mathrm{p}<0.001)$, it can be concluded that the accumulation of toxic metabolites in the rats decreases, which a priori improves the vital processes When studying the parameters of carbohydrate metabolism, the serum glucose level was on average in the group (5.86 \pm 0.39$) \mathrm{mmol} / \mathrm{l}$. The concentration of insulin was slightly elevated and averaged (19.24 $\pm 0.97) \mathrm{mU} / \mathrm{ml}$. The HOMA-IR index was equal to (4.52 \pm 0.43$)$ units, which indicates the expressed insulin resistance in the examined patients. The level of leptin in patients was raised

$(\mathrm{p}<0.05)$ and averaged $(28.17 \pm 3.62) \mathrm{ng} / \mathrm{ml}$, the level of adiponectin was decreased $(\mathrm{p}<0.05)$ and averaged (12.15 \pm 1.86$) \mathrm{ng} / \mathrm{ml}$.

According to the results of ultrasound examination, sonographic signs of hepatic steatosis (diffuse increase in the "brightness" of the hepatic parenchyma, distal echo signal attenuation, vague picture fuzziness, its "fuzziness") were detected in $100 \%$ of patients, hepatomegaly was defined in $77.5 \%$ of patients.

The conducted course of drinking treatment was accompanied by an improvement in the studied indicators, which was not observed in the control group. The use of MDW was characterized by a significant positive dynamics of the clinical course of NAFLD ( $p<0.01$ ), concomitant pathology of the biliary tract ( $p<0.01$ ), and functional bowel diseases that occur with constipation ( $p<0.001)$. The biochemical study demonstrated a pronounced positive effect for the normalization of the level of total bilirubin $(p<0.02)$ and cholestasis markers ( $p<0.05)$. Unfortunately, under the influence of this MDW, there was no leveling of hypertransferase in patients with a minimal degree of activity with steatohepatitis, which is detailed in Table 2. In parallel, there was a significant decrease in the concentration of total cholesterol $(p<0.05)$, ßlipoproteins $\quad(p<0.02)$, a tendency to decrease triglycerides and LDL $(p>0.05)$. Changes in carbohydrate metabolism were characterized by positive dynamics of insulin according to the HOMAIR index ( $p<0.05)$. The change in the level of adipocytokines was characterized by positive dynamics under the influence of course drinking treatment in the main group. The change in the level of adipocytokines was characterized by positive dynamics under the influence of course drinking treatment in the main group.

Conclusion Thus, the experimental studies carried out with the use of low-mineralized sulfate sodium water indicate a significant decrease in the steatosis of the liver according to the morphological study of the biopsy specimens, which was accompanied by an improvement in the functional state of the liver, restoration of the processes of bile formation and bile secretion, a decrease in detoxification at hepatocyte level, and restoration of energy-dependent transmembrane ion transport. Experimental data were confirmed by favorable dynamics of the clinical course of the disease, improvement of the functional state of the liver, normalization of lipid metabolism, as a biochemical marker of NAFLD, a decrease in insulin resistance, and restoration of adiponectin secretion under the influence of the course drinking intake of this MW. All of the above gives grounds for the use of sulphate MW in a complex of measures for the treatment and prevention of the progress of NAFLD. The obtained data justify the expediency of using sulphate MW in the complex treatment of patients with NAFLD in the Morshin resort. Further clinical and experimental studies are planned to achieve understanding of the pathogenesis of NAFLD, and to elucidate the mechanisms of the therapeutic properties of MW of different chemical composition and provide therapy in their use in patients with such severe pathology as NAFLD. 


\section{Bibliography}

1. Stepanov YuM, Abaturov OIe, Zavhorodnia NIu, Skyrda IIu. Nealkoholna zhyrova khvoroba pechinky v ditei: suchasnyi pohliad na mozhlyvosti diahnostyky ta likuvannia (2 chastyna)[ Non-alcoholic fatty liver disease in children: a modern look at the possibilities of diagnosis and treatment (Part 2)].

2. Anstee QM, Targher G, Day CP. Progression of NAFLD to diabetes mellitus, cardiovascular disease or cirrhosis. Nat Rev Gastroenterol Hepatol. 2013; 10:330-344

3. Brunt EM. Non-alcoholic fatty liver disease: what's new under the microscope? Gut. 2011;60:1152-1158.

4. Milaciu MV, Ciumărnean L, Sâmpelean D et al. Noncardiometabolic comorbidities of non-alcoholic fatty liver disease. Balneo Research Journal. 2018;9(2):4349.

5. Wongjarupong N, Assavapongpaiboon B, Susantitaphong $\mathrm{P}$ et al. Non-alcoholic fatty liver disease as a risk factor for cholangiocarcinoma: a systematic review and meta-analysis. BMC Gastroenterol. 2017;8 (17):149.

6. Musso G., Cassader M, Olivetti C et al. Association of obstructive sleep apnoea with the presence and severity of non-alcoholic fatty liver disease. A systematic review and meta-analysis. Obes Rev. 2013;14:417-431.

7. Minushkin ON, Maslovskij LV. Lechenie zhirovoj bolezni pecheni razlichnoj jetiologii: sovremennye rekomendacii [Treatment of fatty liver disease of different etiology: modern recommendations]. Gastrojenterologija. 2013;4:38-44. (in Russian)

8. Mili S, Stimac D. Nonalcoholic fatty liver disease/steatohepatitis: epidemiology, pathogenesis, clinical presentation, treatment. Dig Dis. 2012;30(2):158-162.

9. Zajchenko OE. Terapevticheskie misheni pri nealkogol'noj zhirovoj bolezni pecheni [Therapeutic targets for non-alcoholic fatty liver disease]. Suchasna gastroenterologija. 2014;1:130-138. (in Russian)

10. Zolotareva TA, Babov KD, Nasibullin BA, Kozjavkin VI, Torohtin AM, Jushkovskaja OG. Medicinskaja reabilitacija. K.: KIM, 2012: 496 s. ISBN 978-9661547-91-8 (in Russian).

11. Drahomyretska NV. Rannia kurortna reabilitatsiia ta vidnovliuvalne likuvannia $\mathrm{v}$ hastroenterolohii: Monohrafiia [Early resort reablilatatsiya ta vidnovlyuvalne likuvannya in gastroenterology: Monograph]. Odesa, ORIDU NADU; 2007:176 p.

12. Medical hydrology and balneology environmental aspects / (ed.) F. Maraver, $\quad$ M.Z. Karagulle. Publicaciones Universidad complutense de Madrid, 2012: $\quad 467$ p. $\quad$ ISBN 978-84-669-3482-4.

13. Nasibullin BA, Hushcha SH, Babov KD, Trubka IO, Oleshko OYa, Bakholdina OI. Posibnyk po vidtvorenniu eksperymentalnykh modelei rozpovsiudzhenykh nozolohichnykh form ta yikh veryfikatsiia [A guide to the reproduction of experimental models of common nosological forms and their verification] Odesa, 2018:82. ISBN 978-966-2326-46-8. (in Ukrainian)

14. Soldatova OA. Formirovanie antiagregacionnyh disfunkcij sosudistoj stenki u krys vo fruktoznoj modeli metabolicheskogo sindroma [Formation of antiaggregational dysfunction of the vascular wall in rats in the fructose model of the metabolic syndrome] Fundamental'nye issledovanija. 2015;1-2:380-383.

url: $\quad$ https://www.fundamentalresearch.ru/ru/article/view?id=36908. (in Russian)

15. Babov KD, Gushcha SH, Nikipelova OM, Drahomyretska NV, Zabolotna IB, Nasibullin BA, Tykhokhid LV, Pyrohov AIa. Poltavskyi bishofit biolohichna diia, efektyvnist likuvalnoho zastosuvannia [Poltava bischofite - biological action, the effectiveness of therapeutic use]. Odesa: «POLIHRAF». 2018:102 s. - ISBN 978-966-2326-482 (in Russian).

16. Gushcha SG, Nasibullin BA, Plakida AL, Balashova IV, Trubka LA, Volyanskaya VS, Kalinichenko NV. Investigation of the influence of mineral water with increased content of organic on the development of metabolic syndrome in the experiment. International Journal of Development Research. 2018;8(2): 1900619009. ISBN 2230-9926.

17. Instruction 2010/63/EU of European Parliament and Council on animals used for research and other purposes protection. Official Journal. 2010;276:33-79.

18. Nakaz MOZ Ukrainy vid 28.09.2009 r. № 692 «Pro zatverdzhennia metodychnykh rekomendatsii $\mathrm{z}$ metodiv doslidzhen biolohichnoi dii pryrodnykh likuvalnykh resursiv ta prefor $\neg$ movanykh likuvalnykh zasobiv». (in Ukrainian) 